\title{
AGENCY CONFLICT DALAM PENCAPAIAN PROFITABILITAS DENGAN LEVERAGE SEBAGAI VARIABEL INTERVENING (STUDI PADA PERUSAHAAN SEKTOR RESTORAN, HOTEL DAN PARIWISATA YANG TERDAFTAR DI BURSA EFEK INDONESIA PERIODE 2011-2015)
}

\author{
Raden Bagus Faizal Irany Sidharta ${ }^{1}$ \\ Budi Santoso ${ }^{2}$ \\ I Nyoman Nugraha Ardana Putra ${ }^{3}$
}

\begin{abstract}
Indonesian Government nowadays is focusing to develop the tourism sector area while some problems in companies in sectors of restaurant, hotel and touris, related to institutional ownership, managerial ownership, leverage, and the company profitability. This research then is aimed at analyzing the effect of institutional ownership and managerial ownership on the leverage, at analyzing the effect of institutional ownership and managerial ownership on the profitability, at analyzing the effect of leverage on the profitability, at analyzing the effect of institutional ownership on the profitability through leverage, at analyzing the effect of managerial ownership on the profitability through leverage. This research employed the path analysis. The research showed that institutional ownership have positive and significant effect on the leverage, the managerial ownership has negative and significant effect on leverage, institutional ownership have negative and significant effect on the profitability, managerial ownership has positive and significant effect on the profitability, leverage has negative and significant effect on the profitability, institutional ownership has negative and significant effect on the profitability through leverage, managerial ownership has positive dan significant effect on the profitability through leverage.
\end{abstract}

Keywords : Institutional Ownership, Managerial Ownership, Leverage and Profitability

${ }^{1}$ Mahasiswa Magister Manajemen, Universitas Mataram 2Dosen Pembimbing Utama Magister Manajemen, Universitas Mataram 3Dosen Pembimbing Pendamping Magister Manajemen, Universitas Mataram 


\section{PENDAHULUAN}

Pemerintah Indonesia beberapa tahun terakhir ini memiliki program untuk meningkatkan jumlah wisatawan baik domestik maupun mancanegara untuk datang dan mengunjungi objek-objek wisata yang tersebar di seluruh Indonesia. Sektor pariwisata merupakan sektor yang menjanjikan untuk dapat menopang kondisi ekonomi secara keseluruhan. Dimulainya dengan pencanangan tag line "Visit Indonesia" yang dimulai pada era pemerintahan presiden Susilo Bambang Yudhoyono dengan program MP3EI yakni Master Plan for the Acceleration and Expansion of Indonesia's Economic Development atau Master Plan Percepatan dan Perluasan Pembangunan Ekonomi Indonesia (MP3EI), pemerintah secara bertahap terus menaikkan anggaran untuk mempromosikan pariwsata Indonesia pada dunia.

Program ini pun dilanjutkan oleh pemerintahan Presiden Joko Widodo dengan program Nawa Citanya dan membuat tag line baru yakni "Wonderful Indonesia" yang digunakan untuk mempromosikan Indonesia dan hal ini merupakan bukti kesunggguhan pemerintah untuk mendorong sektor pariwisata untuk berkontribusi lebih banyak. Selain itu juga pemerintah sedang sangat gencar-gencarnya untuk melakukan nation branding Indonesia di mata dunia agar Indonesia dapat lebih dikenal lagi oleh masyarakat dunia sehingga membuat perusahaan yang bergerak dalam bidang restoran, hotel dan pariwisata cukup bergairah. Perusahaan sektor restoran, hotel dan pariwisata digunakan dalam penelitian ini karena adanya dukungan pemerintah yang besar untuk mengembangkan pariwisata Indonesia beserta dengan infrastruktur pendukungnya. Hal ini dibuktikan dengan besarnya anggaran yang di alokasikan pemerintah untuk mendukung promosi pariwisata Indonesia. Pemerintah saat ini mengalokasikan 5,4 triliun rupiah untuk mengembangkan lagi kawasankawasan wisata di Indonesia dan 1 triliun rupiah hanya untuk mempromosikan daerahdaerah wisata Indonesia tersebut (www.kontan.co.id diakses tanggal 25 November 2016). Namun, terdapat beberapa permasalahan yang terjadi pada perusahaan-perusahaan yang bergerak di bidang restoran, hotel dan pariwisata yang terdaftar dalam Bursa Efek Indonesia terkait dengan hubungannya antara kepemilikan institusional, kepemilikan manajerial, leverage atau penggunaan utang dan dampaknya terhadap profitabilitas perusahaan. Terdapat fenomena bahwa rata-rata kepemilikan institusional yang semakin meningkat tiap tahunnya tidak mampu meningkatkan profitabilitas perusahaan, yang terjadi profitabilitas perusahaan berfluktuasi dan bahkan cenderung menurun dan menunjukkan angka yang minus atau rugi. Kepemilikan manajerial yang berfluktuasi tiap tahunnya dan bahkan cenderung dikurangi hal ini akan membuat manajemen perusahaan memiliki tanggung jawab yang rendah terhadap jalannya perusahaan sehingga manajemen perusahaan tidak dapat menunjukkan kinerja terbaiknya. Penggunaan utang yang cukup tinggi belum mampu mengungkit profitabilitas perusahaan. Hal ini dibuktikan dengan rata-rata DER atau penggunaan utang yang cenderung untuk semakin meninggi yang diharapkan mampu untuk "mengungkit" profitabilitas perusahaan, nyatanya tidak bisa membuat profitabilitas "terungkit" tinggi yang terjadi justru profitabilitas menurun. Hal ini dapat dilihat pada Tabel 1.1 seperti berikut: 


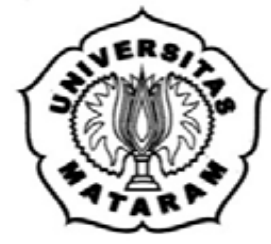

Tabel 1.1 Rata-Rata Kepemilikan Institusional (Institutional Ownership), Kepemilikan Manajerial (Managerial Ownership), Profitabilitas dan Leverage Pada Perusahaan Restoran, Hotel dan Pariwisata Periode 2011-2015 (dalam persen)

\begin{tabular}{|c|c|c|c|c|c|}
\hline \multirow{5}{*}{$\begin{array}{r}\text { Sumber: } \\
\text { www.idx.co.id } \\
\end{array}$} & TAHUN & $\begin{array}{l}\text { Kepemilikan } \\
\text { Institusional }\end{array}$ & $\begin{array}{c}\text { Kepemilikan } \\
\text { Manajerial }\end{array}$ & ROE & DER \\
\hline & 2011 & 63.26 & 12.51 & 5.31 & 58.32 \\
\hline & 2012 & 63.83 & 13.11 & 4.36 & 62.73 \\
\hline & 2013 & 67.13 & 14.19 & 14.16 & 64.24 \\
\hline & 2014 & 68.19 & 8.49 & 3.20 & 79.19 \\
\hline $\begin{array}{c}\text { tanggal 1/ } \\
2016)\end{array}$ & 2015 & 70.37 & 8.09 & -2.91 & 88.76 \\
\hline
\end{tabular}

Dari Tabel 1.1 tersebut rata-rata kepemilikan insitusional atau institusional ownership (IO) pada tahun 2011 sebesar 63.26 persen, sementara kepemilikan manajerial atau managerial ownership (MO) sebesar 12.51 persen dari kombinasi ini rata-rata perusahaan dapat memperoleh return on equity (ROE) sebesar 5.31 persen dengan menggunakan debt to equity (DER) sebesar 58.32 persen, pada tahun 2012 rata-rata kepemilikan institusional meningkat tipis menjadi 63.83 persen dan kepemilikan manajerial meningkat pula menjadi 13.11 persen dan perusahaan memperoleh rata-rata ROE sebesar 4.36 persen dengan DER yang justru meningkat menjadi 62.73 persen hal ini mengindikasikan bahwa utang belum mampu mengungkit profitabilitas, lalu pada tahun 2013 kepemilikan institusional meningkat menjadi 67.13 persen, kepemilikan manajerial pun meningkat menjadi 14.19 persen dengan DER yang semakin meningkat menjadi 64.24 persen dan perusahaan mampu meningkatkan profitabilitasnya menjadi 14.19 persen, pada tahun 2014 kepemilikan institusional meningkat kembali menjadi 68.19 persen, namun kepemilikan manajerial turun drastis menjadi 8.49 persen dan ROE pun menjadi turun drastis menjadi 3.20 persen saja dengan tingkat penggunaan utang yang meningkat menjadi 79.19 persen, pada tahun 2015 kepemilikan institusional meningkat kembali menjadi 70.37 persen lalu kepemilikan manajerial turun tipis menjadi 8.09 persen dan ROE menunjukkan angka sebesar -2.91 persen sementara DER menunjukkan peningkatan yang cukup tajam menjadi 88.76 persen.

Beberapa penelitian telah banyak dilakukan terkait kepemilikan institusional, kepemilikan manajerial, leverage dan profitabilitas seperti penelitian yang dilakukan oleh Wiranata dan Nugrahanti (2013) menunjukkan bahwa leverage berpengaruh positif terhadap profitabilitas, sementara kepemilikan institusional dan kepemilikan manajerial memiliki pengaruh negatif terhadap profitabilitas sedangkan, penelitian yang dilakukan oleh Ardiani dan Ardiyaningsih (2010) menemukan bahwa kepemilikan manajerial memiliki pengaruh positif dan signifikan terhadap kinerja perusahaan dalam hal ini profitabilitas perusahaan dengan menggunakan rasio ROE dan tidak ada pengaruh antara kepemilikan institusional terhadap kinerja perusahaan. Hasil penelitian yang dilakukan oleh Septiana et al (2016) menunjukkan bahwa kepemilikan manajerial dan kepemilikan institusional berpengaruh terhadap profitabilitas perusahaan dan kepemilikan manajerial berpengaruh pula terhadap profitabilitas perusahaan, sementara kepemilikan institusional pun berpengaruh positif terhadap profitabilitas 
perusahaan. Sementara itu, penelitian yang dilakukan Widiastuti et al (2016) memiliki hasil bahwa leverage memiliki pengaruh negatif dan signifikan terhadap profitabilitas perusahaan sementara penelitian yang dilakukan oleh Avitasari et al (2016) memiliki hasil bahwa leverage berpengaruh positif terhadap profitabilitas perusahaan. Dengan adanya fenomena seperti yang dikemukakan diatas dan masih banyaknya terjadi perbedaan hasil penelitian, penulis merasa tertarik untuk melakukan penelitian yang berkaitan dengan kepemilikan institusional, kepemilikan manajerial, leverage dan profitabilitas

\section{TUJUAN PENELITIAN}

Tujuan dari penelitian ini adalah sebagai berikut:

1. Untuk menganalisis pengaruh kepemilikan institusional dan kepemilikan manajerial terhadap leverage pada perusahaan sektor restoran, hotel dan pariwisata

2. Untuk menganalisis pengaruh kepemilikan institusional dan kepemilikan manajerial terhadap profitabilitas pada perusahaan restoran, hotel dan pariwisata

3. Untuk menganalisis pengaruh leverage terhadap profitabilitas pada perusahaan restoran, hotel dan pariwisata

4. Untuk menganalisis pengaruh kepemilikan institusional terhadap profitabilitas melalui leverage pada perusahaan restoran, hotel dan pariwisata

5. Untuk menganalisis pengaruh kepemilikan manajerial terhadap profitabilitas melalui leverage pada perusahaan restoran, hotel dan pariwisata

\section{KAJIAN KEPUSTAKAAN DAN HIPOTESIS}

\subsection{Kajian Kepustakaan}

Teori agensi menjelaskan tentang hubungan kontraktual antara pihak yang mendelegasikan keputusan tertentu (principal/pemilik/pemegang saham) dengan pihak yang menerima pendelegasian tersebut (agen/manajemen). Secara teori, agen memiliki tujuan untuk memakmurkan pemilik perusahaan namun dalam kenyataannya agen atau manajer juga memiliki tujuan-tujuan pribadi yang ingin dicapainya seperti kemakmuran indvidu, keselamatan kerja, gaya hidup, dan keuntungan yang lain seperti kantor yang mewah, keanggotaan professional, fasilitas telepon, mobil pribadi dan tiket liburan yang kesemuanya dibebankan atas biaya perusahaan (Sartono, 2010:10). Sehingga, manajer tidak lagi memiliki tujuan untuk memaksimumkan kemakmuran pemegang saham melainkan mengambil langkah untuk tidak terlalu mengambil risiko untuk mendapatkan keuntungan yang lebih banyak karena hal ini akan dapat mengurangi manajer untuk memperoleh keuntungan pribadinya (Gitman, 2009). Perbedaan tujuan antara pemilik perusahaan dengan manajemen disebut sebagai agency problem (Jensen dan Meckling, 1976)

Dalam teori keagenan munculnya konflik keagenan atau agency conflict ini juga timbul karena adanya asimetri informasi antara principal dan agent. Asimetri informasi ini merupakan terjadinya ketidakseimbangan informasi antara principal dan agent. Agent sebagai orang yang melaksanakan kegiatan perusahaan sehari-harinya bisa saja dapat memberikan informasi yang 
tidak sebenarnya kepada principal yang dapat merugikan pemilik perusahaan (principal). Hal ini disebabkan karena adanya perbedaan kepentingan karena berdasarkan sifat dasar manusia ialah ingin lebih menguntungkan dirinya sendiri. Untuk mencegah terjadinya penyimpangan perilaku dan keputusan manajemen dengan tujuan pemegang saham maka diperlukan pengawasan dan pengendalian yang kuat (Jensen dan Meckling, 1976).

Konflik kepentingan yang terjadi antara pemegang saham dan manajemen ini sering disebabkan ketika perusahaan memiliki lebih banyak kas dari yang dibutuhkan untuk mendukung operasi utama perusahaan. Manajer sering kali menggunakan kelebihan kas ini untuk kepentingan pribadi mereka dan menimbulkan kerugian bagi pemegang saham. Perusahaan dapat mengurangi kelebihan arus kas dengan berbagai macam cara, salah satunya dengan mengalirkannya kembali kepada pemegang saham dalam bentuk dividen yang lebih tinggi atau pembelian saham kembali. Cara yang berikutnya adalah dengan menggeser sasaran struktur modal menuju jumlah utang yang lebih besar dengan harapan persyaratan pelayanan utang yang lebih tinggi akan memaksa manajer lebih disiplin (Jensen dan Meckling,1976). Jika perusahaan gagal membayar utangnya maka perusahaan akan dipaksa untuk bangkrut dan manajer akan kehilangan pekerjaan mereka. Jadi, manajer akan memiliki kemungkinan yang kecil untuk membeli sebuah jet perusahaan baru yang mahal harganya jika perusahaan memiliki arus kas yang besar. Penggunaan leverage bagi perusahaan merupakan salah satu cara yang baik untuk mengurangi kelebihan arus kas (Brigham dan Houston, 2011). Melalui leverage yang digunakan perusahaan tentunya perusahaan mengharapkan adanya peningkatan profitabilitas hal ini dikarenakan bunga utang yang ada dalam leverage tersebut akan menjadi potongan pajak dan pengembalian hasil kepada pemegang saham akan semakin banyak (Keown et al, 2010).

Dengan menggunakan leverage, pemegang saham perusahaan akan menikmati kontrol lebih besar atas tim manajemen, hal ini dikarenakan manajemen dituntut untuk berhati-hati dalam menjalankan operasi perusahaan karena pendanaanya berasal dari utang yang dapat menimbulkan kebangkrutan, lalu dengan penggunaan leverage manajemen bekerja dalam ancaman kegagalan keuangan sehingga ini menuntut manajemen bekerja lebih efisien. Sehingga, ketika manajemen diberikan kesempatan untuk memiliki sejumlah saham perusahaan maka manajer akan menjadi risk averser atau tidak menyukai risiko. Hal ini menunjukkan bahwa semakin tinggi kepemilikan saham yang dimiliki oleh manajemen maka leverage pun akan semakin menurun, ini dikarenakan setiap keputusan yang diambil oleh manajemen akan ikut langsung dirasakan dampaknya oleh manajemen tersebut. Sehingga, manajemen akan lebih berhati-hati dalam penggunaan utang tersebut terlebih akan adanya ancaman kebangkrutan dan mengakibatkan mereka akan kehilangan pekerjaannya (Jensen dan Meckling,1976).

Untuk meredam adanya konflik keagenan tersebut maka perusahaan dapat mengubah struktur kepemilikannya, menjadi kepemilikan saham melalui institusi dan kepemilikan saham yang dimiliki oleh manajemen (Jensen dan Meckling, 1976). Struktur kepemilikan ini akan mempengaruhi berbagai keputusan perusahaan terlebih keputusan perusahaan dalam mencari pendanaan bagi perusahaan yang dapat tercermin dari kondisi struktur modal perusahaan. Perusahaan akan berusaha untuk menentukan struktur modal optimalnya dalam mencapai profitabilitas perusahaan. Kepemilikan saham institusi yang semakin banyak akan 
meningkatkan kualitas pengawasan terhadap jalannya perusahaan sehingga hal ini akan membuat profitabilitas perusahaan diharapkan dapat semakin meningkat. Kepemilikan saham manajerial yang ditingkatkan bertujuan agar manajemen merasa memiliki perusahaan dan tidak berlaku merugikan para pemegang saham, sehingga perilaku manajemen dalam menjalan perusahaan diharapkan akan membawa dampak pada profitabilitas perusahaan yang semakin baik. Hal ini mendorong adanya penyatuan kepentingan antara pemegang saham dan manajemen perusahaan selaku pengelola perusahaan (Jensen dan Meckling, 1976).

\subsection{Hipotesis}

Berdasarkan latar belakang, tujuan penelitian dan kajian kepustakaan maka hipotesis penelitian ini adalah sebagai berikut:

\subsubsection{Pengaruh Struktur Kepemilikan terhadap Leverage}

Dengan menggunakan leverage kepemilikan institusional akan dapat meningkatkan kualitas pengawasan terhadap jalannya perusahaan sehingga hal ini akan membuat profitabilitas perusahaan diharapkan dapat semakin meningkat. Semakin tinggi kepemilikan institusional maka akan semakin kuat kontrol eksternal terhadap perusahaan. Kepemilikan institusional cenderung menggunakan leverage pada perusahaan hal ini dilakukan agar manajemen berhati-hati dalam menjalankan perusahaan. Dengan menggeser sasaran struktur modal menuju jumlah utang yang lebih besar maka utang yang lebih tinggi akan memaksa manajer lebih disiplin (Jensen dan Meckling,1976).

Di sisi lain, beberapa manajer lebih agresif sehingga mereka lebih bersedia untuk menggunakan utang yang tinggi sebagai usaha untuk meningkatkan laba (Brigham dan Houston, 2011). Manajer yang berani menanggung risiko besar (risk seeker), akan memilih memenuhi kebutuhan dengan dana berasal dari utang (Riyanto,2001). Menurut trade-off theory penggunaan utang dalam jumlah yang lebih besar akan mengurangi pajak dan menyebabkan makin banyak laba operasi (EBIT) perusahaan yang mengalir kepada para investor atau pemilik perusahaan (Brigham dan Houston, 2011). Dalam menentukan struktur modal yang optimal teori ini menyatakan bahwa manajer akan berusaha meningkatkan tingkat utang sampai pada satu titik dimana nilai perlindungan pajak bunga tambahan benar-benar terimbangi oleh biaya masalah keuangan.

Menurut, Brailsford et al (2015) terdapat pengaruh yang positif antara kepemilikan manajerial dengan leverage yang dilakukan oleh perusahaan. Sementara penelitian pun dilakukan oleh Chen (2012) memiliki hasil bahwa terdapat pengaruh positif dan signifikan antara struktur kepemilikan dengan kinerja perusahaan yang di proksikan dengan ROE dan terdapat hubungan yang sangat kuat antara struktur kepemilikan dengan profitabilitas perusahaan. Sementara itu, menurut Sadewa dan Yasa (2015:19) peningkatan leverage dapat menambah pengawasan terhadap manajemen sehingga manajemen akan susah bertindak menyimpang dari tujuan perusahaan. Haruman (2008) memiliki hasil Managerial Ownership, Instituional Ownership, dan Dividend Pay Out Ratio (DPR) berpengaruh terhadap Debt to Equity Ratio (DER) sedangkan secara parsial variabel struktur kepemilikan yang terdiri dari 


\section{JMM JURNAL MAGISTER MANAJEMEN UNIVERSITAS MATARAM \\ Maret 2017}

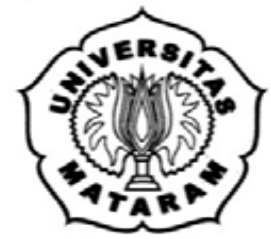

kepemilikan manajerial berpengaruh terhadap debt to equity ratio (DER) dan kepemilikan institusional berpengaruh terhadap debt to equity ratio (DER).

H1 = Diduga kepemilikan institusional berpengaruh positif terhadap leverage

H2 = Diduga kepemilikan manajerial berpengaruh positif terhadap leverage

\subsubsection{Pengaruh Struktur kepemilikan terhadap Profitabilitas}

Kepemilikan institusi yang semakin banyak akan meningkatkan kualitas pengawasan terhadap jalannya perusahaan sehingga hal ini akan membuat profitabilitas perusahaan diharapkan dapat semakin meningkat. Kepemilikan manajerial yang ditingkatkan bertujuan agar manajemen merasa memiliki perusahaan dan tidak berlaku merugikan para pemegang saham, sehingga perilaku manajemen dalam menjalan perusahaan diharapkan akan membawa dampak pada profitabilitas perusahaan yang semakin baik (Jensen dan Meckling, 1976).

Untuk mengurangi kepentingan masing-masing pihak baik dari pemegang saham dan agent maka perusahaan dapat meningkatkan kepemilikan manajerial. Kepemilikan manajerial akan mendorong pihak manajerial untuk berhati-hati dalam mengambil keputusan. Kepemilikan manajerial yang lebih banyak akan membuat para manajer dengan sekuat tenaga untuk dapat menunjukkan dan menghasilkan profitabilitas perusahaan karena mereka ikut merasakan dampak terhadap setiap keputusan yang di ambilnya. Apriadi (2013) menyatakan bahwa semakin tinggi kepemilikan institusional maka semakin kuat kontrol eksternal terhadap perusahaan. Dengan adanya pengawasan yang kuat maka jalannya perusahaan dapat lebih diawasi sehingga dapat meningkatkan kinerja perusahaan yang dapat ditunjukkan dengan peningkatakan profitabilitas. Sementara itu menurut Shelfeir dan Vishny dalam Wiranata dan Nugrahanti (2013) menyatakan bahwa kepemilikan institusional memiliki pengaruh yang kuat dalam setiap pengambilan keputusan perusahaan sehingga hal ini akan berdampak positif bagi perusahaan terutama dari segi kinerja perusahaan. Sementara penelitian pun dilakukan oleh Chen (2012) memiliki hasil bahwa terdapat pengaruh positif dan signifikan antara struktur kepemilikan dengan kinerja perusahaan yang di proksikan dengan ROE dan terdapat hubungan yang sangat kuat antara struktur kepemilikan dengan profitabilitas perusahaan. Sementara itu penelitian yang dilakukan oleh Ardiani dan Ardiyaningsih (2010) memiliki hasil bahwa terdapat pengaruh positif dan signifikan variabel struktur kepemilikan manajerial terhadap kinerja perusahaan

H3 = Diduga kepemilikan institusional berpengaruh positif terhadap profitabilitas perusahaan

H4 = Diduga kepemilikan manajerial berpengaruh positif terhadap profitabilitas perusahaan

\subsubsection{Pengaruh Leverage terhadap profitabilitas perusahaan}

Menurut Sartono (2001:263) leverage adalah penggunaan sumber dana yang memiliki beban tetap dengan harapan bahwa akan memberikan tambahan keuntungan yang lebih besar daripada beban tetapnya sehingga akan meningkatkan keuntungan yang tersedia bagi pemegang saham. Jika perusahaan mendapatkan hasil dari investasi yang didanai dengan dana hasil pinjaman lebih besar daripada bunga yang dibayarkan, maka pengembalian dari modal pemilik akan diperbesar atau diungkit (leverage) (Brigham dan Houston, 2009:101). 
Leverage dapat diukur dengan rasio leverage untuk melihat seberapa besar perbandingan penggunaan utang dengan modal sendiri dalam operasi perusahaan. Menurut Brigham dan Houston (2011:143), kreditor lebih menyukai rasio utang yang rendah karena makin rendah rasio utang, makin besar perlindungan terhadap kerugian kreditor jika terjadi likuidasi. Di sisi lain, pemegang saham mungkin menginginkan penggunaan utang yang lebih tinggi karena penggunaan utang akan memperbesar laba yang diharapkan. Semakin besar penggunaan utang dalam struktur modal maka profitabilitas suatu perusahaan semakin meningkat. Menggunakan lebih banyak utang pada umumnya akan meningkatkan perkiraan pengembalian atas ekuitas (Brigham dan Houston, 2011:155).

Menurut Weston dan Copeland (1997) penggunaan leverage oleh perusahaan dapat meningkatkan profitabilitas perusahaan namun di saat yang bersamaan leverage juga dapat menurunkan profitabilitas perusahaan atau justru membuat perusahaan menjadi rugi. Penelitian yang dilakukan oleh Wiranata dan Nugrahanti (2013) menunjukkan hasil bahwa leverage berpengaruh positif terhadap profitabilitas. Lalu, penelitian yang dilakukan oleh Avitasari, Topowijoyo dan Zahroh (2016) mendapatkan hasil bahwa Debt to Equity Ratio (Leverage) berpengaruh positif terhadap Return On Equity (Profitabilitas) H5 = Diduga leverage berpengaruh positif terhadap profitabilitas perusahaan

\subsubsection{Pengaruh Struktur Kepemilikan Terhadap Profitabilitas Perusahaan Melalui leverage}

Struktur kepemilikan yang di dalamnya terdapat kepemilikan institusional dan kepemilikan manajerial akan mempengaruhi berbagai keputusan perusahaan terlebih keputusan perusahaan dalam mencari pendanaan bagi perusahaan yang dapat tercermin dari kondisi struktur modal perusahaan. Perusahaan akan berusaha untuk menentukan struktur modal optimalnya dalam mencapai profitabilitas perusahaan. Kepemilikan institusional yang semakin banyak akan meningkatkan kualitas pengawasan terhadap jalannya perusahaan sehingga hal ini akan membuat profitabilitas perusahaan diharapkan dapat semakin meningkat. Kepemilikan manajerial yang ditingkatkan bertujuan agar manajemen merasa memiliki perusahaan dan tidak berlaku merugikan para pemegang saham, sehingga perilaku manajemen dalam menjalan perusahaan diharapkan akan membawa dampak pada profitabilitas perusahaan yang semakin baik. Hal ini mendorong adanya penyatuan kepentingan antara pemegang saham dan manajemen perusahaan selaku pengelola perusahaan. Teori keagenan menjelaskan bahwa struktur keuangan dipengaruhi oleh insentif dan perilaku dari pembuat keputusan baik itu pemilik perusahaan (pemegang saham) maupun pihak manajemen (Jensen dan Meckling, 1976)

Kepemilikan institusional dapat menggunakan leverage sebagai salah satu cara untuk memonitor manajemen dalam menjalankan operasi perusahaan. Hal ini dilakukan karena perusahaan memiliki ancaman terjadinya kebangkrutan yang akan menyebabkan manajer kehilangan pekerjaan. Tentunya hal ini membuat manajer lebih berhati-hati dalam menjalankan operasi perusahaan. Penggunaan leverage juga akan memiliki dampak pada meningkatkan profitabilitas perusahaan.

Penggunaan utang yang lebih tinggi akan memperbesar laba yang diharapkan. Semakin besar penggunaan utang dalam struktur modal maka profitabilitas suatu perusahaan semakin meningkat. Menggunakan lebih banyak utang pada umumnya akan 
meningkatkan perkiraan pengembalian atas ekuitas (Brigham dan Houston, 2011:155). Menurut trade-off theory dalam menentukan struktur modal yang optimal teori ini menyatakan bahwa manajer akan berusaha meningkatkan tingkat utang sampai pada satu titik dimana nilai perlindungan pajak bunga tambahan benar-benar terimbangi oleh biaya masalah keuangan.

Penelitian yang dilakukan Larasati (2011) memiliki kepemilikan institusional memiliki pengaruh positif dan signifikan terhadap kebijakan hutang. Penelitian yang dilakukan oleh Chen (2012) memiliki hasil bahwa terdapat pengaruh Positif dan signifikan antara struktur kepemilikan dengan kinerja perusahaan yang di proksikan dengan ROE dan terdapat hubungan yang sangat kuat antara struktur kepemilikan dengan profitabilitas perusahaan. Penelitian yang dilakukan oleh Brailsford, Oliver dan Pua (2015) memiliki hasil bahwa terdapat hubungan yang kuat antara kepemilikan institusional dengan leverage perusahaan, terdapat hubungan antara kepemilikan manajerial dengan leverage perusahaan.

H6 = Diduga kepemilikan institusional berpengaruh positif terhadap profitabilitas perusahaan melalui leverage

H7 = Diduga kepemilikan manajerial berpengaruh positif terhadap profitabilitas perusahaan melalui leverage

\section{METODE PENELITIAN}

Jenis penelitian ini adalah penelitian asosiatif-kausalitas (sebab-akibat). Populasi dalam penelitian ini adalah seluruh perusahaan sektor restoran, hotel dan pariwisata yang terdaftar di Bursa Efek Indonesia sebanyak 21 perusahaan. Teknik sampling menggunakan teknik purposive sampling dan menghasilkan sampel sebanyak 9 perusahaan. Pengujian hipotesis dalam penelitian ini menggunakan model analisis jalur (path analysis). Analisis jalur (Path Analysis) digunakan untuk menganalisis pola hubungan kausal antar variabel dengan tujuan mengetahui pengaruh langsung dan tidak langsung secara serempak atau mandiri beberapa variabel penyebab terhadap sebuah variabel akibat.

\section{HASIL DAN PEMBAHASAN}

Uji asumsi klasik yang di dalamnya termasuk uji normalitas data tidak ditampilkan dalam penelitian ini karena model-model fungsi untuk pengujian hipotesis-hipotesis penelitian ini di analisis dengan menggunakan regresi data panel. Menurut Verbeek (2000), penggunaan model regresi data panel tidak mensyaratkan untuk dilakukan uji asumsi klasik karena dalam penggunaan jenis data panel, peneliti diperbolehkan untuk mengidentifikasi parameter tertentu tanpa perlu membuat asumsi yang ketat atau tidak mengharuskan terpenuhinya semua asumsi klasik regresi linier pada OLS. Selain itu, syarat normalitas pada data dianggap sudah terpenuhi karena keseluruhan observasi data variabel adalah merupakan penjumlahan dari data observasi secara cross section dan time series sehingga jumlah data dalam penelitian ini dianggap cukup besar untuk juga didukung oleh prinsip Central Limit Theorem (CLT). 


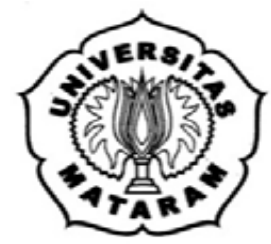

Hasil Regresi Sub-struktur 1

Pada hasil regresi sub-sturktur 1 ditampilkan hasil regresi antara kepemilikan institusional terhadap leverage seperti pada tabel di bawah ini :

\begin{tabular}{crrrr} 
& \multicolumn{4}{c}{ Tabel 5.1 Hasil Regresi Sub-struktur 1 } \\
Variable & Coefficient & Std. Error & t-Statistic & Prob. \\
\hline \hline C & -36.95042 & 33.84743 & -1.091676 & 0.2811 \\
IO? & 1.616621 & 0.343789 & 4.702368 & 0.0000
\end{tabular}

Pengaruh antara kepemilikan institusional (X1) terhadap leverage (Y1) mempunyai nilai koefisien jalur sebesar 1.616 dan bertanda positif. Hal ini berarti jika terjadi perubahan nilai pada kepemilikan institusional sebesar satu satuan maka leverage akan berubah sebesar 1.616. Nilai signifikansi dari pengaruh kepemilikan institusional terhadap leverage menunjukkan angka 0.000 yang berarti lebih kecil dari nilai probabilitas yang di standarkan sebesar 0.05. Ini berarti pengaruh kepemilikan institusional terhadap leverage berpengaruh secara signifikan. Dengan kata lain, kepemilikan institusional berpengaruh positif dan signifikan terhadap leverage. Jika kepemilikan intitusional naik sebesar satu satuan maka leverage akan naik sebesar 1.616.

Penelitian ini sesuai dengan penelitian yang dikemukakan oleh Haruman (2008) bahwa terdapat pengaruh yang positif antara kepemilikan institusional terhadap leverage. Hal ini menunjukkan bahwa kepemilikan institusional cenderung untuk menggunakan tingkat utang yang tinggi. Sesuai dengan teori keagenan yang menyatakan bahwa dengan menggunakan utang yang cukup tinggi hal ini akan memaksa manajer lebih disiplin (Jensen dan Meckling,1976). Jika perusahaan gagal membayar utangnya maka perusahaan akan dipaksa untuk bangkrut dan manajer akan kehilangan pekerjaan mereka. Sehingga dengan menggunakan leverage, pemegang saham perusahaan akan menikmati kontrol lebih besar atas tim manajemen, hal ini dikarenakan manajemen dituntut untuk berhati-hati dalam menjalankan operasi perusahaan karena pendanaanya berasal dari utang yang dapat menimbulkan kebangkrutan. Menurut trade-off theory penggunaan utang dalam jumlah yang lebih besar akan mengurangi pajak dan menyebabkan makin banyak laba operasi (EBIT) perusahaan yang mengalir kepada para investor atau pemilik perusahaan (Brigham dan Houston, 2011)

\section{Hasil Regresi Sub-struktur 2}

Pada hasil regresi sub-sturktur 2 ditampilkan hasil regresi antara kepemilikan manajerial terhadap leverage seperti pada tabel di bawah ini :

Tabel 5.2 Hasil Regresi Sub-struktur 2

\begin{tabular}{crrrr} 
Variable & Coefficient & Std. Error & t-Statistic & Prob. \\
\hline \hline C & 100.2130 & 26.65415 & 3.759753 & 0.0005 \\
MO? & -2.620590 & 0.414531 & -6.321820 & 0.0000
\end{tabular}


Pengaruh antara kepemilikan manajerial (X2) terhadap leverage (Y1) mempunyai nilai koefisien jalur sebesar -2.620 dan bertanda negatif. Hal ini berarti jika terjadi perubahan nilai pada kepemilikan manajerial sebesar satu satuan maka leverage akan berubah sebesar -2.620. Nilai signifikansi dari pengaruh kepemilikan institusional terhadap leverage menunjukkan angka 0.0000 yang berarti lebih kecil dari nilai probabilitas yang di standarkan sebesar 0.05 . Ini berarti pengaruh kepemilikan manajerial terhadap leverage berpengaruh secara signifikan. Dengan kata lain, kepemilikan manajerial berpengaruh negatif dan signifikan terhadap leverage. Jika kepemilikan manajerial naik sebesar satu satuan maka leverage akan turun sebesar -2.620 .

Penelitian ini berbeda dengan hasil penelitian yang dilakukan oleh Larasati (2011), yang menyatakan tidak terdapat pengaruh antara kepemilikan manajerial dengan leverage. Dalam penelitian ini terdapat pengaruh negatif dan signifikan antara kepemilikan manajerial dengan leverage. Hal ini menunjukkan bahwa ketika kepemilikan manajerial ditambah maka manajer akan menjadi risk averser atau tidak menyukai risiko. Hal ini menunjukkan bahwa semakin tinggi kepemilikan saham yang dimiliki oleh manajemen maka leverage pun akan semakin menurun, ini dikarenakan setiap keputusan yang diambil oleh manajemen akan ikut langsung dirasakan dampaknya oleh manajemen tersebut. Sehingga, manajemen akan lebih berhati-hati dalam penggunaan utang tersebut terlebih akan adanya ancaman kebangkrutan dan mengakibatkan manajemen akan kehilangan pekerjaannya (Jensen dan Meckling,1976).

\section{Hasil Regresi Sub-struktur 3}

Pada hasil regresi sub-sturktur 3 ditampilkan hasil regresi antara kepemilikan institusional terhadap profitabilitas seperti pada tabel di bawah ini :

Tabel 5.3 Hasil Regresi Sub-struktur 3

\begin{tabular}{crrrr} 
Variable & Coefficient & Std. Error & t-Statistic & Prob. \\
\hline \hline C & 18.76357 & 6.924335 & 2.709801 & 0.0096 \\
IO? & -0.209355 & 0.094960 & -2.204661 & 0.0329
\end{tabular}

Pengaruh antara kepemilikan institusional (X1) terhadap profitabilitas (Y2) mempunyai nilai koefisien jalur sebesar -0.2093 dan bertanda negatif. Hal ini berarti jika terjadi perubahan nilai pada kepemilikan manajerial sebesar satu satuan maka profitabilitas akan berubah sebesar -0.2093. Nilai signifikansi dari pengaruh kepemilikan institusional terhadap profitabilitas menunjukkan angka 0.0329 yang berarti lebih kecil dari nilai probabilitas yang di standarkan sebesar 0.05. Ini berarti pengaruh kepemilikan institusional terhadap profitabilitas berpengaruh secara signifikan. Dengan kata lain, kepemilikan institusional berpengaruh negatif dan signifikan terhadap profitabilitas. Jika kepemilikan institusional naik sebesar satu satuan maka profitabilitas perusahaan akan turun sebesar -0.2093.

Hal ini menunjukkan bahwa ketika kepemilikan institusional ditambah maka akan terjadi penurunan pada profitabilitas perusahaan sektor restoran, hotel dan pariwisata. Penelitian ini berbeda dengan hasil penelitian yang dilakukan oleh Ardianingsih dan Ardiyani (2010) dan Wiranata dan Nugrahanti (2011). Berdasarkan laporan keuangan dan laporan 
tahunan yang di umumkan kepada masyarakat pada periode pengamatan tahun 2011 hingga tahun 2015, perusahaan sektor restoran, hotel dan pariwisata ini sebenarnya dimiliki oleh pribadi pemilik perusahaan itu sendiri namun menggunakan institusi untuk membeli saham perusahaannya sendiri untuk memenuhi prinsip-prinsip good corporate governance yang ditetapkan pemerintah sehingga dalam pelaksanaannya walaupun sudah ada kepemilikan melalui institusi hal ini justru tidak membuat pengawasan terhadap manajemen dan jalannya perusahaan untuk mencapai profitabilitas menjadi tidak maksimal sehingga dalam penelitian ini ditunjukkan dengan pengaruh yang negatif. Melalui kepemilikan institusional tersebut, pemilik perusahaan atau pemegang saham menggunakan hal tersebut untuk dapat meraih keuntungan pribadinya yang menyebabkan jalannya pengawasan menjadi tidak terlaksana dengan baik.

Berdasarkan perspektif teori keagenan, bahwa dengan adanya kepemilikan institusional maka diharapkan pengawasan akan semakin efektif, namun yang terjadi pada perusahaan sektor restoran, hotel dan pariwisata ini adalah adanya "persekongkolan" antara institusi dan manajemen perusahaan. Dimana masih banyaknya ditemukan pemilik perusahaan yang menggunakan institusi untuk membeli sejumlah saham perusahaannya sendiri. Hal ini membuktikan bahwa perusahaan pada sektor restoran, hotel dan pariwisata tidak menjalankan teori keagenan yang menyatakan bahwa dengan adanya kepemilikan institusional maka pengawasan dapat ditingkatkan dan perusahaan dapat menunjukkan kinerjanya yang tercermin dalam pencapaian profitabilitasnya.

\section{Hasil Regresi Sub-struktur 4}

Pada hasil regresi sub-sturktur 4 ditampilkan hasil regresi antara kepemilikan manajerial terhadap profitabilitas seperti pada tabel di bawah ini :

\begin{tabular}{crrrr}
\multicolumn{5}{c}{ Tabel 5.4 Hasil Regresi Sub-struktur 4 } \\
Variable & Coefficient & Std. Error & t-Statistic & Prob. \\
\hline \hline C & 1.605488 & 2.822232 & 0.568872 & 0.5724 \\
MO? & 0.285760 & 0.137796 & 2.073783 & 0.0441
\end{tabular}

Pengaruh antara kepemilikan manajerial (X2) terhadap profitabilitas (Y2) mempunyai nilai koefisien jalur sebesar 0.2857 dan bertanda positif. Hal ini berarti jika terjadi perubahan nilai pada kepemilikan manajerial sebesar satu satuan maka profitabilitas akan berubah sebesar 0.2857. Nilai signifikansi dari pengaruh kepemilikan institusional terhadap profitabilitas menunjukkan angka 0.0441 yang berarti lebih kecil dari angka signifikansi sebesar 0.05 sehingga kepemilikan manajerial berpengaruh secara signifikan terhadap profiatbilitas. Dengan kata lain kepemilikan manajerial berpengaruh positif dan signifikan terhadap profitabilitas. Jika kepemilikan manajerial bertambah sebesar satu satuan maka profitabilitas perusahaan akan ikut bertambah sebesar 0.2857 .

Penelitian ini sejalan dengan penelitian yang dilakukan oleh Ardianingsih dan Ardiyani (2010) serta penelitian yang dilakukan oleh Septiana et al (2016) bahwa teradapat pengaruh positif dan signifikan antara kepemilikan manajerial terhadap profitabilitas 
perusahaan. Hal ini sesuai dengan teori keagenan bahwa dengan diberikannya kesempatan manajer untuk dapat memiliki perusahaan maka akan tercipta penyelarasan atau penyatuan kepentingan antara pemegang saham dengan manajemen sehingga dapat mengurangi konflik kepentingan yang terjadi dan dapat memotivasi manajemen perusahaan untuk meningkatkan kinerja dan tanggung jawab untuk meningkatkan kesejahteraan para pemegang saham dimana manajer itu sendiri merupakan pemilik dari perusahaan (Jensen dan Meckling, 1976).

Sehingga, dengan ditingkatkannya kepemilikan manajerial maka akan dapat meningkatkan profitabilitas perusahaan. Kepemilikan manajerial yang ditingkatkan pun akan membuat manajer berhati-hati dalam mengambil keputusan karena mereka akan ikut merasakan dampak dari setiap keputusan yang mereka ambil sendiri. Hasil penelitian ini juga membuktikan teori keagenan yang menyatakan bahwa dengan diberikannya manajemen untuk ikut memiliki perusahaan maka manajemen akan berusaha sekuat tenaga untuk dapat menunjukkan kinerja terbaiknya yang dapat dilihat dengan pencapaian profitabilitas perusahaan.

\section{Hasil Regresi Sub-struktur 5}

Pada hasil regresi sub-sturktur 5 ditampilkan hasil regresi antara leverage terhadap profitabilitas seperti pada tabel di bawah ini :

Tabel 5.5 Hasil Regresi Sub-struktur 5

\begin{tabular}{crrrr} 
Variable & Coefficient & Std. Error & t-Statistic & Prob. \\
\hline \hline C & 9.909942 & 3.536345 & 2.802312 & 0.0076 \\
DER? & -0.071915 & 0.030111 & -2.388334 & 0.0214
\end{tabular}

Pengaruh antara leverage (Y1) terhadap profitabilitas (Y2) mempunyai nilai koefisien jalur sebesar -0.0719 dan bertanda negatif. Hal ini berarti jika terjadi perubahan nilai pada leverage sebesar satu satuan maka profitabilitas akan berubah sebesar -0.0719. Nilai signifikansi dari pengaruh kepemilikan institusional terhadap profitabilitas menunjukkan angka 0.0214 yang berarti lebih kecil dengan angka signifikansi sebesar 0.05 sehingga leverage berpengaruh secara signifikan terhadap profiatbilitas. Dengan kata lain leverage berpengaruh negatif dan signifikan terhadap profitabilitas. Jika leverage bertambah sebesar satu satuan maka profitabilitas perusahaan akan menurun sebesar -0.0719 .

Penelitian ini sejalan dengan hasil penelitian yang dilakukan oleh Alima (2015), Hamid dan Kusrina (2015) dan penelitian yang dilakukan oleh Widiastuti et al (2016). Terdapat pengaruh yang negatif dan signifikan antara leverage dengan profitabilitas perusahaan. Hal ini menunjukkan bahwa pada perusahaan sektor restoran, hotel dan pariwisata penggunaan utang yang dilakukan tidak mampu meningkatkan profitabilitas perusahaan. Semakin tinggi leverage berarti akan berakibat pada bertambahnya beban perusahaan terhadap kreditur atau pihak luar perusahaan dan hal ini terjadi pada perusahaan sektor restoran, hotel dan pariwisata yang menggunakan leverage yang cukup tinggi dan berdampak pada menurunnya profitabilitas perusahaan.

Menurut pecking order theory perusahaan-perusahaan yang profitable umumnya meminjam dalam jumlah yang sedikit hal in dikarenakan perusahaan-perusahaan tersebut 
memerlukan external funding yang sedikit. Namun, perusahaan-perusahaan yang kurang profitable cenderung akan memiliki utang yang lebih besar karena alasan dana internal yang dimiliki tidak cukup untuk membiayai perusahaan (Brealey,2007). Apabila melihat kembali pada deskripsi data dalam penelitian ini, maka dapat dikatakan perusahaan-perusahaan sektor restoran, hotel dan pariwisata perusahaan yang kurang profitable hal ini dibuktikan dengan rendahnya nilai profitabilitas perusahaan dalam kurun waktu periode pengamatan pada tahun 2011-2015 sehingga perusahaan lebih banyak menggunakan external funding yang dibuktikan dengan angka leverage yang cukup tinggi.

\section{Hasil Perhitungan Sub-struktur 6}

Dalam penelitian ini, terdapat pengaruh tidak langsung antara variabel kepemilikan institusional (X1) terhadap profitabilitas melalui leverage. Dari hasil analisa tersebut, maka untuk menghitung pengaruh tidak langsung tersebut adalah sebagai berikut :

- Kepemilikan institusional terhadap profitabilitas melalui leverage

$$
1.616 x-0.0791=-0.1278
$$

Dari perhitungan tersebut, memberi arti bahwa terdapat pengaruh tidak langsung antara variabel kepemilikan institusi dengan profitabilitas melalui variabel leverage dengan nilai koefisien jalur sebesar -0.1278. Perbandingan pengaruh tidak langsung kepemilikan institusional terhadap profitabilitas melalui leverage dengan pengaruh langsungnya antara kepemilikan institusional terhadap profitabilitas diperoleh hasil $-0.1278<-0.2093$ sehingga bisa dinyatakan bahwa leverage berfungsi sebagai parsial intervening dalam pengaruh kepemilikan institusional terhadap profitabilitas pada perusahaan.

Hasil penelitian ini menunjukkan bahwa kepemilikan institusional berpengaruh negatif terhadap profitabilitas melalui leverage. Artinya, semakin tinggi kepemilikan intitusional perusahaan maka akan semakin rendah profitabiltas perusahaan melalui leverage. Hasil penelitian ini juga menunjukkan bahwa dengan menggunakan leverage baik secara langsung maupun tidak langsung akan dapat menurunkan profitabilitas perusahaan. Ketika kepemilikan institusional menggunakan leverage pun hal ini juga akan menurunkan profitabilitas perusahaan.

Perusahaan sektor restoran, hotel dan pariwisata pun menggunakan leverage untuk meningkatkan profitabilitasnya namun profitabilitas perusahaan sektor restoran, hotel dan pariwisata tidak meningkat yang terjadi profitabilitas semakin menurun dan perusahaan justru rugi. Hal ini mengindikasikan bahwa perusahaan sektor restoran, hotel dan pariwisata dalam menggunakan utang tersebut sudah tidak lagi memiliki tujuan untuk mencapai profitabilitas. Ini bisa dilihat dari besarnya leverage yang digunakan oleh perusahaan dan disaat yang bersamaan profitabilitas perusahaan tidak meningkat. Hal ini sesuai dengan teori sinyal yang menyatakan bahwa perusahaan berusaha menutupi operasional perusahaannya dengan menarik utang dan tidak lagi berfokus pada pencapaian profitabilitas perusahaannya. Hal ini akan berdampak pada seperti yang dikemukakan dalam teori sinyal bahwa dengan menggunakan utang yang tinggi maka akan mempengaruhi prospek perusahaan.Ketika tingkat utang yang digunakan perusahaan terlalu tinggi maka hal ini akan memberikan sinyal kepada investor bahwa perusahaan dalam kondisi kurang profitable yang berarti prospek perusahaan kurang cerah. Perusahaan dengan prospek yang kurang baik akan lebih senang 
pendanaan dengan ekuitas dari luar (Brigham dan Houston, 2011). Sehingga, hasil dari penelitian ini menunjukkan bahwa terdapat pengaruh antara kepemilikan institusional terhadap profitabilitas perusahaan baik secara langsung maupun tidak langsung. Hal ini berarti bahwa leverage sebagai variabel intervening bersifat sebagian atau parsial.

\section{Hasil Perhitungan Sub-struktur 7}

Dalam penelitian ini, terdapat pengaruh tidak langsung antara variabel kepemilikan manajerial (X2) terhadap profitabilitas melalui leverage. Dari hasil analisa tersebut, maka untuk menghitung pengaruh tidak langsung tersebut digunakan formulasi sebagai berikut :

- Pengaruh Kepemilikan Manajerial Terhadap Profitabilitas Melalui Leverage

$$
-2.620 x-0.0791=0.2072
$$

Dari perhitungan tersebut, memberi arti bahwa terdapat pengaruh tidak langsung antara variabel kepemilikan manajerial dengan profitabilitas melalui variabel leverage dengan nilai koefisien jalur sebesar 0.2072. Perbandingan pengaruh tidak langsung kepemilikan manajerial terhadap profitabilitas melalui leverage dengan pengaruh langsungnya antara kepemilikan manajerial terhadap profitabilitas diperoleh hasil $0.2072<0.2857$ sehingga bisa dinyatakan bahwa leverage dapat berfungsi sebagai parsial intervening dalam pengaruh kepemilikan manajerial terhadap profitabilitas pada perusahaan.

Hasil penelitian ini menunjukkan bahwa kepemilikan manajerial berpengaruh positif terhadap profitabilitas melalui leverage. Artinya, semakin tinggi kepemilikan manajerial perusahaan maka akan semakin tinggi profitabiltas perusahaan melalui leverage. Hasil penelitian ini juga menunjukkan bahwa dengan menggunakan leverage baik secara langsung maupun tidak langsung akan dapat meningkatkan profitabilitas perusahaan. Ketika manajemen diberikan kesempatan untuk memiliki perusahaan maka manajer akan berusaha menggunakan utang yang kecil hal ini dikarenakan ketika perusahaan menggunakan utang yang tinggi maka terdapat ancaman kebangkrutan yang akan menyebabkan manajer kehilangan pekerjaannya.Sehingga, manajemen akan lebih berhati-hati dalam penggunaan utang tersebut terlebih akan adanya ancaman kebangkrutan dan mengakibatkan mereka akan kehilangan pekerjaannya dengan menggunakan utang yang rendah maka diharapkan akan meningkatkan profitabilitas perusahaan. (Jensen dan Meckling,1976).

Hal ini sesuai dengan pecking order theory yang menetapkan suatu urutan keputusan pendanaan dimana perusahaan pertama kali akan memilih untuk menggunakan laba ditahan, kemudian utang dan menerbitkan ekuitas baru sebagai pilihan terakhir. Pecking order theory menjelaskan perusahaan mempunyai urutan preferensi dalam memilih sumber pendanaan. Donaldson (1961) dalam Marjani (2016) mengungkapkan bahwa manajer lebih menyukai pendanaan internal kecuali bila terjadi kekurangan dana. Sehingga, manajer akan berusaha untuk menggunakan pendanaan internal terlebih dahulu baru menggunakan pendanaan eksternal. Manajer akan berusaha menggunakan struktur modal yang optimal artinya manajer akan berusaha menggunakan utang untuk meningkatkan profitabilitas perusahaan. Menurut Riyanto (2013:375-376), perusahaan yang menggunakan dana dengan beban tetap dikatakan menghasilkan leverage yang menguntungkan (favorable financial leverage) atau efek positif kalau pendapatan yang diterima dari penggunaan dana tersebut lebih besar daripada beban tetap 
dari penggunaan dana itu. Sehingga manajer akan berusaha menggunakan struktur modal yang optimal untuk dapat mengungkit profitabilitas.

Hasil penelitian ini juga sesuai dengan teori keagenan bahwa dengan diberikannya kesempatan manajer untuk dapat memiliki perusahaan maka akan tercipta penyelarasan atau penyatuan kepentingan antara pemegang saham dengan manajemen sehingga dapat mengurangi konflik kepentingan yang terjadi dan dapat memotivasi manajemen perusahaan untuk meningkatkan kinerja dan tanggung jawab untuk meningkatkan kesejahteraan para pemegang saham dimana manajer itu sendiri merupakan pemilik dari perusahaan (Jensen dan Meckling, 1976). Sehingga, hasil dari penelitian ini menunjukkan bahwa terdapat pengaruh antara kepemilikan manajerial terhadap profitabilitas perusahaan baik secara langsung maupun tidak langsung. Hal ini berarti bahwa leverage sebagai variabel intervening bersifat sebagian atau parsial.

\section{KESIMPULAN}

Berdasarkan analisis data yang dilakukan, dapat disimpulkan bahwa kepemilikan institusional berpengaruh positif dan signifikan terhadap leverage perusahaan sektor restoran, hotel dan pariwisata, kepemilikan manajerial berpengaruh negatif dan signifikan terhadap leverage perusahaan sektor restoran, hotel dan pariwisata, kepemilikan institusional berpengaruh negatif dan signifikan terhadap profitabilitas perusahaan sektor restoran, hotel dan pariwisata, kepemilikan manajerial berpengaruh positif dan signifikan terhadap profitabilitas perusahaan sektor restoran, hotel dan pariwisata, leverage berpengaruh negatif dan signifikan terhadap profitabilitas perusahaan sektor restoran, hotel dan pariwisata, kepemilikan institusional berpengaruh negatif dan signifikan terhadap profitabilitas melalui leverage, kepemilikan manajerial berpengaruh positif dan signifikan terhadap profitabilitas melalui leverage.

Implikasi dari penelitian ini adalah bagi perusahaan sektor restoran, hotel dan pariwisata, perlu untuk menerapkan prinsip-prinsip good corporate governance secara benar. Perusahaan perlu menambah komisaris independen dan direktur independen dalam perusahaan. Hal ini penting dilakukan untuk dapat meningkatkan profitabilitas perusahaan agar kepemilikan institusional yang ada dalam perusahaan dapat mengawasi jalannya perusahaan secara maksimal dan nantinya akan berdampak kepada pencapaian profitabilitas perusahaan, manajemen perusahaan perlu diberikan kesempatan untuk memiliki perusahaan hal ini dikarenakan ketika manajemen ikut memiliki perusahaan maka berpengaruh dengan meningkatnya terhadap profitabilitas perusahaan karena manajemen juga ikut merasa memiliki perusahaan, perusahaan perlu memperhatikan penggunaan utang. Hal ini dikarenakan dengan menggunakan utang yang terlalu tinggi justru akan membuat perusahaan merugi. Sehingga, diperlukan penentuan kembali struktur modal yang optimal agar dapat mencapai profitabilitas perusahaan, perusahaan sektor restoran, hotel dan pariwisata perlu menyeimbangkan porsi antara kepemilikan institusional dan kepemilikan manajerial hal ini dikarenakan akan berdampak pada pencapaian profitabilitas perusahaan. Sementara bagi investor sebaiknya memperhatikan struktur kepemilikan secara cermat. Investor perlu memperhatikan prinsip-prinsip good corporate governance yang ada di dalam 
perusahaan, investor perlu dengan seksama memperhatikan laporan-laporan keuangan dan laporan tahunan perusahaan dengan baik dan mampu menganalisanya sehingga keputusan yang akan di ambil menjadi tepat, Investor perlu menganalisa kembali penggunaan leverage perusahaan. Agar leverage yang digunakan perusahaan benar-benar dapat meningkatkan pengembalian kepada pemegang saham dan bukan menjadikan kerugian bagi investor

\section{DAFTAR PUSTAKA}

Alima, S.2015.Pengaruh Struktur Modal Terhadap Profitabilitas Pada Perusahaan Industri Tekstil Dan Garment Yang Terdaftar di Bursa Efek Indonesia. Jurnal Fakultas Ilmu Sosial dan Ilmu Politik,2, 1-13

Avitasari et al.2016. Pengaruh Financial Leverage Terhadap Profitabilitas Perusahaan (Studi pada Perusahaan Manufaktur Sektor Aneka Industri Sub Sektor Otomotif dan Komponen yang Terdaftar di BEI Periode 2012-2014) Journal Administrasi Bisnis,32,98105

Ardianingsih, A \& Ardiyani,K.2010.Analisis Pengaruh Struktur Kepemilikan Terhadap Kinerja Perusahaan. Jurnal Pena,19, 97-109

Brailsford et al.2015. Theory and Evidence On The Relationship Between Ownership Structure and Capital Sturcture.Australia National University Journal,1,1-34

Brigham, E. F.\&Houston, J. F. 2011. Fundamentals Of Financial Management-Dasar-Dasar Manajemen Keuangan, Jakarta, The Dryden Press.

Chen,L.2012.The Effect of Ownership Structure On Firm Performance.Aarhus School Of Busines Journal,1,1-65

Jensen, M. C.\& Meckling, W. H.1976. Theory of The Firm: Managerial Behavior, Agency Costs and Ownership Structure. Journal of Financial Economics,3,305-360.

Keown et al.2010.Manajemen Keuangan:Prinsip dan Penerapan, Jakarta, PT.Indeks

Kurniawati et al.2015. Pengaruh Financial Leverage Terhadap Profitabilitas (Studi pada Perusahaan Industri Kimia yang Listing di BEI Period 2009-2013.Jurnal Administrasi dan Bisnis,1,1-9

Larasati.2011.Pengaruh Kepemilikan Manajerial, Kepemilikan Institusional dan Kebijakan Deviden Terhadap Kebijakan Hutang Perusahaan.Jurnal Ekonomi Bisnis,2,103-107

Riyanto, Bambang. 2013. Dasar-Dasar Pembelanjaan Perusahaan. Yogyakarta: BPFE-Yogyakarta.

Sadewa, N \& Yasa G,W, 2016. Pengaruh Corporate Governance dan Leverage Pada Agency Cost. Jurnal Ilmiah Akuntansi dan Bisnis,11, 17-27

Sartono, M. 2010. Manajemen Keuangan Teori dan Aplikasi Yogyakarta, BPFE-YOGYAKARTA.

Septiana et al.2016. Pengaruh Mekanisme GCG (Struktur kepemilikan) terhadap Profitabilitas Perusahaan (Studi pada Perusahaan Makanan dan Minuman Tahun 2011-2014).Jurnal Administrasi Bisnis,38,147-155 


\section{$J M M$ UNRAM

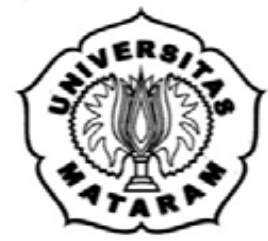

Verbeek, Marno. 2000. A Guide to Modern Econometrics. John Wiley \& Sons, Ltd.

Widiastuti et al.2016. Pengaruh Leverage, Ukuran Perusahaan, Pertumbuhan Perusahaan, Rasio Likuiditas, Rasio Aktivitas Terhadap Profitabilitas (Studi Pada Sektor Keuangan dan Perbankan Periode 2010-2014).Journal Of Accounting,2,1-8

Wiranata, Y A \& Nugrahanti, Y,W.2013.Pengaruh Struktur Kepemilikan Terhadap Profitabilitas Perusahaan Manufaktur di Indonesia.Jurnal Akuntansi dan Keuangan,15,1526 